\title{
Strategi Gerakan Sosial Transnasioal dalam Kampanye Perdamaian Internasional (Studi Kasus: Food Not Bombs)
}

\author{
Ahmad Tarikhul Haq \\ Husein Abdullah \\ Pusparida Syahdan \\ ahmadtarikhulhaq@gmail.com \\ Department of International Relations, Hasanuddin University \\ Makassar, Indonesia
}

\begin{abstract}
This study focused on transnational social movement strategies in international peace campaign with Food Not Bombs as study case. This study used analytical descriptive method with library research as data collection method. The data type is secondary one which obtained from literatures, books, journals, and information accessed via internet that related with the issues. Analytical techniques used by the author in this paper are qualitative data analysis and quantitative data analysis which used to complement the first one. The result of this study are food distribution as antiwar and poverty symbol and message to public, transnational coalition building, and nonviolence method usage. Transnational coalition used to bring more people to their collective claim. Food Not Bombs dedication towards nonviolence shown in its nonviolence protest act such as blockade, marches, and camps.
\end{abstract}

Keywords: social movements; Food Not Bombs

\begin{abstract}
ABSTRAK
Penelitian ini membahas tentang strategi transnational social movement - gerakan sosial transnasional dalam kampanye perdamaian internasional dengan menggunakan studi kasus Food Not Bombs. Penelitian ini menggunakan metode deskriptif analitik, dengan tehnik pengumpulan data yakni dengan studi kepustakaan, kemudian jenis data yang digunakan adalah data sekunder, yang diperoleh dari literatur-literatur, buku-buku, dokumen, jurnal, dan informasi yang diakses melalui internet yang berkaitan dengan masalah yang dibahas, dan tehnik analisis yang digunakan penulis dalam penulisan ini adalah tehnik analisis data kualitatif, adapun data kuantitatif merupakan data pelengkap untuk menjelaskan data kualitatif. Hasil penelitian ini menunjukkan bahwa strategi Food Not Bombs berupa membagikan makanan sebagai pesan anti perang dan kelaparan kepada publik, membangun koalisi transnasional, dan menggunakan metode nonkekerasan. Koalisi transnasional digunakan untuk membawa pesan kolektif dengan massa yang lebih besar. Begitu pula dengan dedikasi Food Not Bombs terhadap nonkekerasan ditandai dengan aksi protes nonkekerasan seperti blokade, kemah, dan pawai.
\end{abstract}

Kata Kunci: gerakan sosial; Food Not Bombs

\section{PENDAHULUAN}

Munculnya interaksi lintas negara yang melibatkan aktor non-negara semakin memperkaya ruang lingkup studi hubungan internasional. Hal ini salah satunya disebabkan oleh adanya internasionalisasi yang terjadi (Tarrow, 2005). Internasionalisasi ini kemudian memberi kesempatan bagi aktor domestik untuk bergerak, bertemu, atau membentuk koalisi yang melintasi batas negaranya. Proses tersebut melibatkan pula adanya sebuah identitas kolektif yang terbangun. Identitas kolektif ini adalah sebuah proses dimana para aktor mengenali diri mereka sendiri dan diakui oleh aktor lainnya sebagai bagian dari pengelompokan yang lebih 
luas dan terbangunnya ketertarikan emosional terhadapnya (Della Porta, 2006). Hal inilah yang kemudian membentuk sebuah gerakan sosial begitu pula dengan gerakan sosial kontemporer atau baru - gerakan sosial baru.

Isu yang diangkat oleh gerakan ini sendiri beragam dan tidak seperti gerakan sosial yang terdahulu yang membahas masalah kelas ekonomi dan kesenjangan sosial namun fokusnya bersifat plural. Oleh karena fokusnya bersifat plural maka gerakan sosial baru umumnya bersifat global dan tidak terbagi-bagi (non-segmental) (Singh, 2010). Gerakan sosial transnasional ini kemudian mengalami perkembangan dalam hal kuantitas dan metodemetode yang bervariasi. Salah satu variasi gerakan yang berkembang di beberapa dekade terakhir adalah gerakan yang tidak menggunakan kekerasan (non-violence movement). Gerakan ini sendiri dipopulerkan oleh Mahatma Ghandi di India dengan gerakan ahimsa (tanpa kekerasan) untuk mencapai kemerdekaan di India. Variasi-variasi wacana yang diangkat oleh gerakan ini pun berbeda satu sama lain.

Banyak gerakan yang terpengaruh oleh pemikiran Mahatma Ghandi ini salah satunya adalah Food Not Bombs yang bermula di Seabrook, Amerika Serikat pada 24 Mei tahun 1980. Food Not Bombs merupakan gerakan nonviolence - nirkekerasan yang menggunakan makanan gratis sebagai alternatif untuk menciptakan perdamaian. Seperti perkataan Dwight D. Eisenhower (Mc.Henry, 2012), "Every gun that is made, every warship launched, every rocket fired signifies, in the final sense, a theft from those who hunger and are not fed, those who are cold and are not clothed." Perkataan dari Dwight D. Eisenhower menurut salah satu pendiri Food Not Bombs Keith McHenry adalah penggambaran sederhana akan alasan gerakan ini berdiri. (Mc.Henry, 2012). Gerakan ini mencoba untuk menyebarkan pesan kepada masyarakat bahwa seharusnya uang itu seharusnya dibelanjakan untuk kebutuhan manusia bukan untuk kebutuhan militer.

Isu-isu yang diangkat oleh Food Not Bombs sendiri tidak terbatas pada isu lokal namun lebih banyak memprotes dan membantu untuk mengorganisir gerakan untuk menghentikan perang atau kebijakan militer sebuah negara, salah satu contohnya adalah pada isu perang El Salvador (Mc.Henry, 2012). Disinilah awal perluasan isu yang diangkat oleh Food Not Bombs yang tidak hanya membicarakan isu dan dampak yang terjadi di lokal negaranya namun banyak memprotes kebijakan militer negara lain seperti kebijakan intervensi Kanada terhadap perang di Afghanistan.

Perang dan kelaparan merupakan masalah yang dihadapi masyarakat dunia yang belum tertangani sampai saat ini. Food Not Bombs kemudian menjadi salah satu gerakan sosial yang dibangun dengan tujuan untuk mengatasi permasalahan tersebut dengan menggunakan prinsip nonviolence (nonkekerasan). Pertumbuhan gerakan ini sangat cepat selama 30 tahun terakhir dengan cabang-cabangnya yang tersebar di seluruh dunia. Menggunakan prinsip nonviolence gerakan ini membagikan makanan kepada orang-orang dalam menyebarkan kampanyenya terhadap perang dan kelaparan.

Cabang dari Food Not Bombs sendiri bekerja secara otonomi. Prinsip utama yang mengikat mereka adalah dedikasi untuk menyediakan makanan gratis kepada orang-orang yang membutuhkan di tempat publik. Gerakan ini bukanlah sebuah gerakan amal tetapi sebuah gerakan yang saling menguntungkan dengan cara mengajak orang untuk berkumpul, memasak, dan membagikan makanan. Pada saat membagikan makanan mereka kemudian menyatakan pandangan politiknya. Slogan yang diadopsi oleh Food Not Bombs adalah "people feeding people, communicates the energy of the people wanting to provide material needs for themselves and others, and their independence from government hand" (Rejer, 2011)

Semakin banyaknya isu yang diangkat membuat beberapa orang di Negara lain kemudian ikut untuk membangun cabang Food Not Bombs di Negaranya masing-masing diantaranya di Spanyol, Australia, Praha, Kanada dan Inggris. Di tahun 1992 Food Not Bombs kemudian mengadakan pertemuan internasional pertamanya di Boston yang dihadiri oleh 75 orang dari 30 kelompok Food Not Bombs yang berbeda termasuk beberapa anggota Food Not Bombs di Kanada (Mc.Henry, 2012). Di pertemuan ini ditetapkan tiga prinsip dari Food Not Bombs 
yaitu 1.) setiap cabang memiliki otonomi sendiri, tidak ada pemimpin, dan memakai konsensus untuk menentukan keputusan; 2.) makanan yang dibagikan adalah makanan vegan dan gratis untuk semua orang tanpa ada batasan tertentu; 3.) gerakan ini adalah gerakan tanpa kekerasan (non-violence direct action).

Food Not Bombs sebagai salah satu gerakan anti nuklir dan gerakan anti perang telah banyak terlibat dalam dalam protes dan kampanye terhadap perang. Pada tahun Februari 2003 ratusan kota di berbagai dunia membagikan makanan kepada para orang-orang yang memprotes invasi Amerika Serikat di Irak. Sementara di bulan yang sama The Danish Peace Foundation memberikan penghargaan Danish Peace Prize kepada Food Not Bombs cabang Copenhagen. Di kota London, Inggris pada bulan Juli dan Agustus tahun 2006, Food Not Bombs cabang London kembali mengadakan protes terhadap invasi Amerika Serikat ke Irak. Beberapa protes terhadap invasi militer yang terjadi selama beberapa tahun terakhir menandakan aktifnya Food Not Bombs dalam menentang rezim militer yang ada. Gerakan ini pun terkadang tidak bergerak secara sendiri dalam mengkampanyekan isu anti perangnya. Ada beberapa gerakan lain yang didukung oleh gerakan ini seperti War Resisters League, Afghan For Peace, dan Veterans For Peace. Bentuk dukungannya adalah dengan memberikan makanan kepada gerakan-gerakan ini selama melakukan protesnya sehingga protes mereka dapat berlangsung dalam waktu yang cukup lama tanpa memperhatikan permasalahan logistiknya.

Food not Bombs sebagai gerakan yang mengkampanyekan anti perang tentunya memiliki strategi dalam mengkampanyekan perdamaian internasional. Apalagi ketika melihat semakin intensnya kenaikan anggaran militer negara-negara di dunia. The New York Times melaporkan bahwa penjualan senjata di dunia oleh perusahaan senjata kepada negaranegara mencapai 55,2 milyar dollar amerika ditahun 2008 (Mc.Henry, 2012). Uang tersebut tentu saja berasal dari masyarakat yang membayar pajak dari negara masing-masing. Sumber daya yang bisa digunakan untuk pendidikan dan perawatan kesehatan digunakan untuk kebijakan yang dapat merugikan masyarakat itu sendiri.

Perubahan sosial yang ingin dicapai oleh Food Not Bombs adalah dengan mengalihkan anggaran militer menuju ke anggaran untuk mengatasi kelaparan yang terjadi di dunia, menghilangkan adanya kelangkaan makanan, dan mengakhiri budaya kekerasan dengan budaya kerjasama, kesetaraan, dan perdamaian. Mantan Presiden Amerika Serikat pada tahun 1999 berkata bahwa "The message is clear, there can be no peace until people have enough to eat. Hungry people are not peaceful people." (Mc.Henry, 2012). Telah banyak Negara yang membelanjakan anggaran negaranya untuk persiapan militer dan perang sementara kelaparan semakin menyebar di seluruh dunia. Dua hal ini yang kemudian coba diatasi oleh Food Not Bombs untuk menciptakan perdamaian internasional dengan saling membantu dengan gerakan anti perang yang lain.

Kampanye akan anti perang dan perdamaian menjadi hal yang sering ditemui di berbagai Negara. Gerakan sosial yang dibentuk oleh masyarakat yang menentang perang banyak bermunculan di berbagai negara. Kampanye untuk penghentikan intervensi militer, pembelanjaan senjata, dan invasi terhadap negara lain hingga sampai kampanye terhadap keadilan sosial. Food Not Bombs sebagai salah satu gerakan sosial nonkekerasan yang ikut berpartisipasi untuk mengangkat isu-isu seperti ini. Gerakan sosial ini pun dalam beberapa tahun semenjak dibentuk kemudian menyebar dan memiliki cabang-cabang hampir di setiap negara.

Penelitian ini mencoba untuk menjelaskan bagaimana proses gerakan sosial domestik menjadi sebuah gerakan transnasional dan melihat strategi yang digunakan gerakan sosial tersebut dalam kampanye perdamaian. Penulis mengambil Studi Kasus Food Not Bombs dikarenakan melihat perkembangannya yang sangat pesat dan tingkat penyebarannya yang intens serta metode pencapaian tujuannya yang unik. Penulis akan meneliti dan memetakan strategi dari gerakan sosial tersebut lalu menuliskan faktor peluang dan hambatan. Data yang digunakan akan dibatasi di beberapa cabang-cabang gerakan sosial tersebut untuk menentukan strategi dasar dari gerakan sosial ini serta beberapa aksi internasional yang 
dilakukan oleh Food Not Bombs.

Peneliti akan membahas asal mula Food Not Bombs dan proses menyebarnya gerakan ini ke seluruh dunia. Peneliti pula akan membahas beberapa model kampanye yang dilakukan oleh gerakan ini di beberapa kota di berbagai negara. Model-model kampanye ini tentu saja akan memiliki sebuah prinsip umumnya yang menjadi dasar pelaksanaan kampanye tersebut. Akan pula terbahas mengenai keberagaman model kampanye yang dilakukan oleh Food Not Bombs. Peneliti akan menjabarkan beberapa aksi transnasional yang dilakukan oleh Food Not Bombs. Aksi transnasional yang dimaksud adalah ada koordinasi lintas negara untuk membangun sebuah aksi maupun aksi yang menargetkan sebuah peristiwa transnasional.

\section{KERANGKA ANALISIS}

Globalisasi menjadi faktor pendukung utama jaringan komunikasi antar individu pun semakin mudah dan padat. Hal ini menjadikan interkasi antarmanusia semakin massiv yang kemudian mengorganisasikan dirinya menjadi aktor non-negara. Untuk mencapai tujuannya, aktor nonnegara bisa menyelaraskan di luar batas negara untuk menghasilkan agenda bersama. Selain itu, perilaku aktor non-negara juga dapat mempengaruhi aktor negara maupun pendapat publik. Interkoneksi terjadi antara aktor non-negara dan aktor negara kemudian menghasilkan bentuk aksi kolektif transnasional (Baharuddin, 2019).

Semakin besarnya aksi kolektif transnasional menjadi penggerak munculnya geraka-gerakan sosial. Gerakan sosial kemudian berkembang sebagai respon terhadap fenomena-fenomena global. Terdapat dua fokus yang menjadi pembahasan dalam penelitian ini yaitu proses perubahan gerakan Food Not Bombs dari gerakan sosial domestik menjadi sebuah gerakan transnasional dan strategi gerakan tersebut dalam kampanye global perdamaian.

Di akhir 1960, dunia mengalami sebuah perubahan besar bahkan menuju ke sebuah revolusi. Gerakan anti perang yang berkembang di Amerika, revolusi 1968 di Prancis, protes mahasiswa di Jerman, Inggris, atau Meksiko, koalisi mahasiswa dan buruh di Italia, serta awal pergerakan wanita dan lingkungan yang menjadi tonggak pembentukan politik di tahun 1970an. Fenomena-fenomena ini menandakan akan adanya sebuah tindakan perubahan yang mendalam. Studi gerakan sosial mulai menarik perhatian para peneliti dikarenakan meluas dan semakin banyaknya fenomena-fenomena seperti di atas. Di tahun 1940 sampe 1960an gerakan sosial belum memiliki teori yang banyak dan belum memiliki peran yang banyak di studi sosial. Barulah di pertengahan 1970an studi tentang gerakan sosial menjadi area penelitian yang diminati oleh banyak peneliti. Hasilnya di akhir tahun 1980, banyak komentator mengatakan bahwa terjadi ledakan tulisan secara teori dan empiris mengenai gerakan sosial dan aksi kolektif (Navvaro, 2008).

Aktor dari social movement akan memiliki konfik politik ataupun secara budaya yang bermaksud untuk membangun perubahan sosial atau melawan perubahan sosial. Konflik yang dimaksudkan adalah hubungan berlawanan antar aktor baik itu secara ekonomi, politik , maupun sosial yang menegasikan klaim satu sama lain yang berujung pada adanya gangguan kepentingan dari aktor yang lainnya. Dense informal network yang dimaksudkan adalah antara individu dan aktor yang terorganisir dengan mempertahankan independensi dan otonominya, mereka secara berkelanjutan saling mengolah sumber daya mereka secara bersama untuk menuju tujuan bersama. Seluruh kegiatan berupa inisiatif, tata kerja, dan strategi bergantung pada negosiasi permanen antara aktor.

Gerakan sosial merupakan tempat bagi identitas secara kolektif berkembang. Collective identity (identitas kolektif) dapat digambarkan dengan adanya pengakuan dan pembentukan keterhubungan satu sama lain. Tujuan yang sama dan komitmen untuk sebuah tujuan dapat membuat seorang individu atau sebuah organisasi mengakui bahwa mereka terikat atau terhubung dengan aktor yang lain dalam mobilisasi kolektif yang lebih luas.

Gerakan sosial sendiri menurut Charles Tilly (1978) memiliki empat komponen yaitu (Wienclaw, 2011) :

a. Groups that form to protest against something (laws, ideals, practices) are typically organized; they are not hap-hazard or disjointed groups, though the form of organization 


\begin{abstract}
may vary;
b. Collective action mobilizes the resources (people, materials, communication channels) that are available to them in order to achieve their goals;

c. Groups engaged in collective action share common interests such as a belief in the injustice of the oppression of women, minorities or gay people;

d. Collection action typically utilizes opportunity.
\end{abstract}

Berdasarkan hal di atas maka dapat diambil kesimpulan bahwa menurut Charles Tilly, gerakan sosial merupakan sebuah aksi kolektif yang melakukan protes terhadap sesuatu yang seringkali terinstitusi dengan menggunakan segala sumber daya yang mereka miliki dan kelompok yang terlibat dalam aksi kolektif ini memiliki kepentingan yang sama. Aksi kolektif ini pula pada umumnya memanfaatkan kesempatan yang ada untuk melakukan gerakan. Darnovsky, Epstein, dan Flacks mengidentifikasikan gerakan sosial sebagai aksi kolektif yang berubah menjadi sebuah gerakan ketika pelakunya menolak untuk menerima sebuah aturan terinstitusi.

Pada tahun 1960an dan tahun 1970an para penstudi gerakan sosial melihat adanya perbedaan gerakan yang terjadi di Amerika dan Eropa. Sifat gerakan yang dulunya berorientasi pada wacana anti kapitalisme, revolusi kelas, dan perjuangan kelas telah berubah menjadi gerakan yang berorientas pada isu yang plural. Para penstudi di Eropa menamakan gerakan ini sebagai New Social Movement-Gerakan Sosial Baru. Wilayah aksi dan cara mobilisasi gerakan sosial baru bersifat global. Begitu pula dengan perhatian sosial dan isu-isu yang bergulir di gerakan ini menyeberangi batas-batas bangsa dan masyarakat.

Di dalam gerakan ini terjadi sebuah proses politik domestik yang mempengaruhi proses politik internasional dan begitu pula sebaliknya. Proses- proses ini diantaranya adalah contention domestik ke konflik internasional dan institusi. Antara lain; diffusion, yaitu transfer atas klaim atau bentuk contention dari satu tempat ke tempat lain dan scale shift yaitu koordinasi antara aksi kolektif di level yang berbeda dari level pertama gerakan itu bermula (Tarrow, 2005).

Penulis akan menggunakan proses diffusion dalam menjelaskan proses transnasionalisasi Food Not Bombs. Adapula dimensi-dimensi transnasionalitas sebuah gerakan sosial yang dipaparkan oleh Hermann Maiba. Dimensi-dimensi tersebut antara lain transnational network; spaces; ideas, tactics, and resources; political opportunity structures; collective identity. Dimensi-dimensi ini berguna untuk mengenali tindakan dan strategi sebuah transnational gerakan sosial.

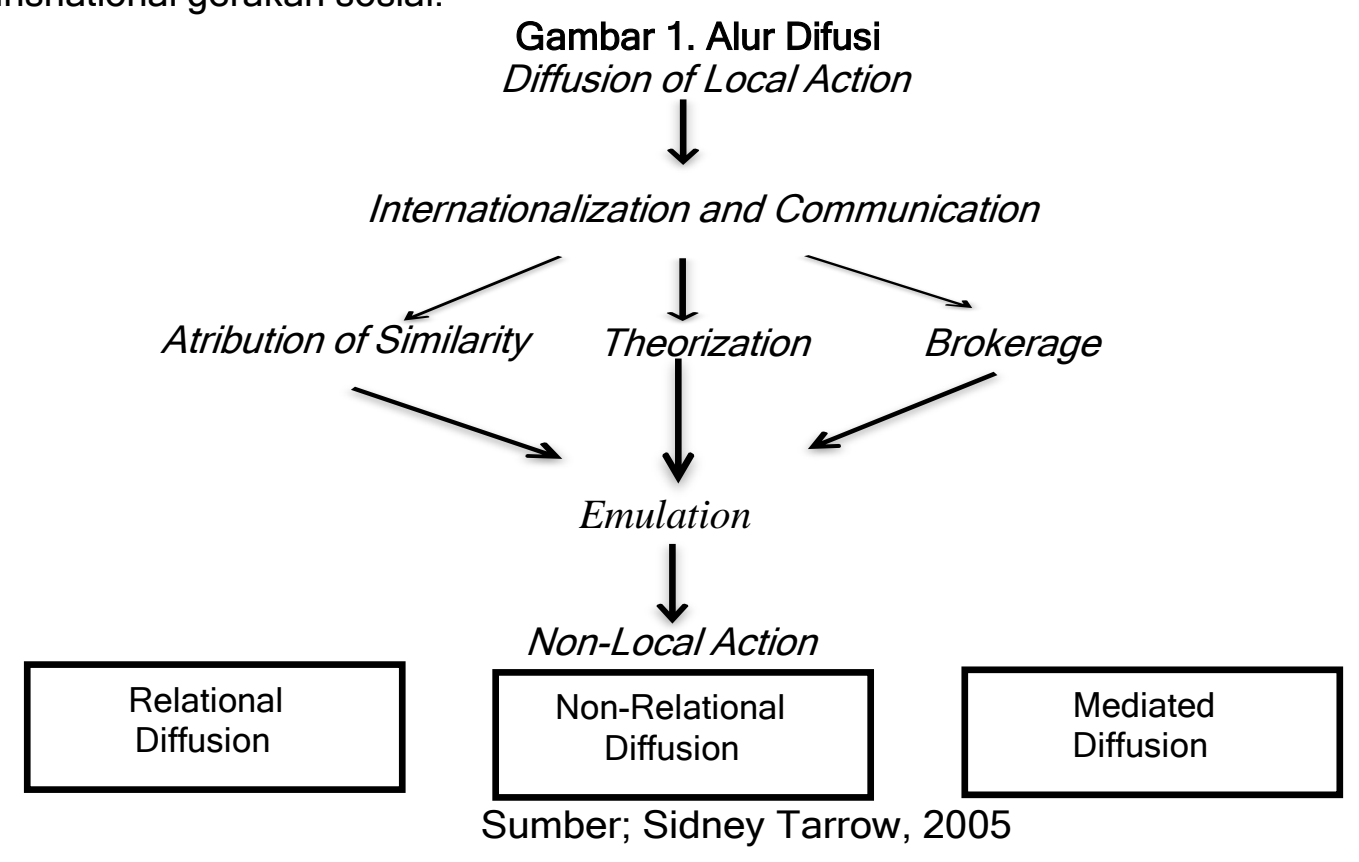


Gambar 1 menunjukkan penggambaran sederhana dari ketiga proses diffusion yang dijelaskan oleh Sageman. Setiap alur memiliki mekanisme utama, alur pertama adalah attribution of similarity (kesamaan atribut), kedua theorization, dan terakhir melalui brokerage. Setelah melalui hal tersebut akan terjadi peniruan yang dilakukan oleh aktor lain di luar dari aksi tersebut berasal. Peniruan yang dimaksudkan berupa sebuah aksi kolektif meniru aksi kolektif yang lain. Melalui penjelasan diffusion maka dapat diketahui proses tumbuhnya gerakan sosial menjadi transnasional dengan adanya sebuah identitas kolektif yang semakin luas melintasi sebuah negara. Proses pengadopsian frame aksi kolektif sehingga terjadi peniruan di tempat lain dapat menjelaskan proses pembangunan gerakan sosial semakin meluas pula. Diffusion pula menjelaskan adanya brokerage yang dilakukan oleh aktor untuk memperkenalkan frame dari sebuah gerakan sosial. Dengan demikian gerakan sosial yang domestik dapat berkembang menjadi transnasional.

Proses dan dimensi-dimensi di atas akan memudahkan untuk memahamai gambaran Jackie Smith et al. (1997) yaitu: "Social movement may be said to be transnational when they involve conscious efforts to build transnational cooperation around shared goals that include social change. Through regular communication, organizations, and activist are able to share technical and strategic information, coordinate parallel activities, or even to mount truly transnational collective action. Like national social movement transnational ones incorporate a range of political actors including individuals, church groups, professional associations and other social groups. Movements are distinguished by the actors and resources they mobilize and in the extent to which they communicate, consult, coordinate, and cooperate in the international arena (Cohen, 2000)."

Dari penggambaran di atas transnational gerakan sosial merupakan sebuah gerakan yang melibatkan aktor-aktor lintas negara. Para aktor tersebut kemudian bertukar informasi dan bahkan melakukan aksi kolektif secara transnasional. Dimensi transnational network menjelaskan bagaimana pengorganisiran komunikasi tersebut melalui transnational spaces. $\mathrm{Hal}$ ini akan memudahkan untuk melihat proses terjadinya maupun alur pembuatan strategi dalam gerakan Food Not Bombs.

Penulis pula akan menggunakan teori positive peace yang dikemukakan oleh Johan Galtung dalam menganalisis hubungan antara kampanye perdamaian internasional dan prinsipprinsip serta aksi yang dimiliki oleh Food Not Bombs. Perdamaian positif akan menjelaskan hubungan antara aksi dan strategi yang dilakukan oleh Gerakan Food Not Bombs dengan Perdamaian Internasional.

Johan Galtung mengatakan bahwa perdamaian adalah ketidakhadiran dari kekerasan, tidak hanya kekerasan personal atau langsung tetapi juga kekerasan struktural atau tidak langsung. Kekerasan struktural adalah ketidakmerataan distribusi kekayaan dan sumber daya serta ketidakseimbangan kekuasaan utnuk menentukan distribusi sumber daya tersebut. la memformulasikan ketidakhadiran kekerasan dan kehadiran keadilan sosial. Masing-masing terbagi menjadi negative peace dan positive peace. Para penstudi perdamaian umumnya menggunakan pembagian tersebut. Negative peace merujuk kepada ketidakhadirannya perang atau kekerasan langsung dan positive peace merujuk kepada kehadirannya keadilan dan hubungan yang tidak eksploitatif sehingga akar penyebab konflik semakin berkurang (Navarro, 2008).

Dalam Journal of Peace Research, Johan Galtung menolak konsep kekerasan yang diartikan kondisi dimana "human beings are being influenced so that their actual somatic and mental realizations are below their potential realizations." (Navvaro, 2008) Konsep ini mengartikan kekerasan sebagai tindakan oleh aktor yang secara sengaja menyebabkan gangguan kesehatan, membuat bagian tubuh cacat, pembunuhan sebagai tingkat tertinggi. Konsep tersebut menurut Galtung terlalu sempit untuk menjelaskan hubungan dari kekerasan dan perdamaian yang ideal. Oleh karena itu diperlukan adanya perluasan konsep kekerasan. 


\section{METODE PENELITIAN}

Tipe penelitian deskriptif-analitik adalah tipe penelitian yang digunakan penulis. Deskriptifanallitik yakni menggambarkan, mencatat, menganalisis serta menginterpretasikan kondisikondisi atau peristiwa-peristiwa yang terkait dengan permasalahan. Kemudian hasil uraian tersebut dilanjutkan untuk menarik kesimpulan yang bersifat analitik. Tipe penelitian deskriptif-analitik bertujuan untuk memberikan gambaran mengenai fenomena yang terjadi yang relevan dengan masalah yang diteliti. Penelitian diharapkan dapat memberikan kejelasan akan strategi Food Not Bombs dalam kampanye perdamaian secara global.

Teknik pengumpulan data yang penulis gunakan dalam penelitian ini adalah telaah pustaka (library research) yaitu dengan cara mengumpulkan data dari literatur yang berhubungan dengan permasalahan yang akan dibahas, dan kemudian menganalisanya. Literatur ini berupa buku-buku, dokumen, jurnal-jurnal, majalah, surat kabar, dan situs-situs internet ataupun laporan-laporan yang berkaitan dengan permasalahan yang akan penulis teliti. Selain daripada itu, teknik wawancara juga dilakukan guna mendapatkan data primer dari para pakar ahli gerakan sosial dan Perdamaian maupun pihak pihak terkait. Bahan-bahan tersebut akan diperoleh dari berbagai tempat baik dari perpustakaan maupun instansi terkait lainya.

Metode penulisan yang penulis gunakan adalah metode deduktif, dimana penulis terlebih dahulu akan menggambarkan permasalahan secara umum, lalu kemudian menarik kesimpulan yang bersifat khusus. Penulis akan menjelaskan secara umum mengenai gerakan Food Not Bombs dalam kampanye global perdamaian serta keterlibatannya dan kemudian menganalisis peran Food Not Bombs dalam kampanye perdamaian lalu menarik kesimpulan berdasarkan hasil analisis tersebut.

\section{HASIL DAN PEMBAHASAN}

Pembangunan stasiun nuklir di Seabrook pada akhir tahun 1979 menjadi pemicu terbentuknya beberapa kelompok yang berusaha untuk menghentikan pembangunan pembangkit bertenaga nuklir tersebut. Pada tanggal 24 Mei 1980 Keith McHenry, Mira Brown, C.T Lawrence Butler, Jessie Constable, Susan Eaton, Brian Feigenbaum, Amy Rothstien, dan Jo Swanson bergabung dalam Coalition for Direct Action di Seabrook bersama dengan 4.000 aktivis lainnya untuk menduduki pembangkit tenaga nuklir Seabrook. Usaha yang dilakukan adalah dengan menempatkan badan mereka di depan kendaraan alat berat untuk menghalangi pembangunan pembangkit tenaga listrik tersebut (Keith McHenry, 2012). Usaha pendudukan ini menandai permulaan dari Food Not Bombs.I

Brian Feigenbaum, salah satu mahasiswa Universitas Boston ditangkap oleh polisi dalam aksi protes terhadap pembangkit listrik bertenaga nuklir Seabrook. Keith McHenry bersama dengan 30 orang membentuk usaha perlawanan hukum terhadap ditangkapnya Brian. Untuk mencari dana mereka menjual kue dan melakukan teater jalanan dengan memakai seragam tentara Amerika. Mereka pula memasang poster yang bertuliskan "it will be a great day when our schools get all the money they need and the air force has to sold bake goods to buy a bomber." Kelompok ini kemudian menemukan cara berkampanye setelah melakukan aksi tersebut (Keith McHenry, 2012).

Mereka pula menulis serta memasang publikasi mengenai pembantaian aktivis HAM di EI Salvador. Mereka membuat tulisan "MONEY FOR FOOD NOT FOR BOMBS" di dinding bangunan publik dan pinggir jalan depan toko-toko. Mereka menamai diri mereka sebagai Clamshell Aliiance namun pada saat itu menurut Keith McHenry banyak orang yang tidak tahu untuk apa organisasi tersebut berdiri (Keith McHenry, 2010). Mereka kemudian memikirkan sebuah nama yang lebih sederhana dalam menggambarkan gerakan yang mereka miliki. Nama Food Not Bombs terpilih setelah beberapa nama sebelumnya, sebuah nama yang memiliki pesan bahwa sumber daya kita seharusnya digunakan untuk makanan bukan untuk bom (Keith McHenry, 2010).

Pada bulan Oktober 1981, kelompok ini mengadakan aksi berjalan sebagai bentuk solidaritas atas blokade misil Pershing 2 oleh warga Jerman. Di Bulan yang sama mereka mengadakan 
pula aksi "Music and March to End the Arms Race." Aksi tersebut dilakukan di Laboratorium Draper yang kemudian menjadi salah pembuat teknologi senjata militer dan senjata nuklir. Aksi tersebut dilakukan dengan cara nonkekerasan (Keith McHenry, 2010).

Di tahun 1982 kelompok ini mengorganisir sebuah aksi konser Nuclear Disarmament. Tentu saja dengan kembali mengumpulkan makanan dan membagikan makanan gratis kepada para orang-orang yang berada dalam protes tersebut. Beberapa musisi dan seniman berkumpul untuk mempertunjukkan keahlian mereka di tempat tersebut. Ribuan orang-orang berkumpul di sana untuk menikmati pertunjukan dan makanan yang dibagikan oleh Food Not Bombs (Keith McHenry, 2010).

Kelompok ini kembali mengadakan aksi respon terhadap diadakannya 2nd Special Session UN General Assembly on Nuclear Disarmament di Central Park New York. Aksi besar ini dihadiri oleh aktivis dari seluruh dunia yang menentang senjata nuklir. Food Not Bombs dalam aksi tersebut membagikan makanan ke ratusan orang (Keith McHenry, 2010).

Food Not Bombs kemudian mengalami perluasan wilayah aksi dengan bertambahnya beberapa cabang di dalam Amerika Serikat. Cabang kedua Food Not Bombs berada di San Fransisco. Food Not Bombs San Fransisco pada aksi pertamanya memberikan makanan kepada para aktivis yang memblokade pembangunan situs nuklir di Nevada. Relawan membagikan makanan sambil berbincang mengenai pesan politik dan mengajak untuk ikut terlibat dalam berbagai proyek FNB di literature table mereka. Cabang FNB ini mengadakan pertemuan setiap minggunya dimana salah satu agenda yang mereka sebut Solidarity yang membahas bagaimana menyiapkan makanan kemana dan menyesuaikan aksi tersebut ke jadwal rutin mereka. Pada saat yang sama ada kelompok yang mengumpulkan dan membagikan makanan di Long Beach, California (Keith McHenry, 2010).

Setiap cabang dari Food Not Bombs berdiri sendiri atau memiliki otonomi tersendiri dan menggunakan konsensus untuk memutuskan sebuah keputusan. Penentuan keputusan secara konsensus dipilih sebagai upaya untuk mewujudkan usaha pembuatan ruang untuk pemberdayaan diri. Konsensus pula dipilih dikarenakan untuk menghindari adanya dominasi dalam menentukan arah setiap cabang oleh beberapa orang saja. ${ }^{52}$ Food Not Bombs tidak memiliki pemimpin, presiden, ataupun direktur dan tidak ada markas pusat. Dalam artian tidak ada pusat komando yang mengatur hal-hal apa yang harus dilakukan oleh cabang-cabang Food Not Bombs.

Food Not Bombs bukan sebuah gerakan amal melainkan gerakan yang berdedikasi pada perubahan melalui nonkekerasan. Relawan Food Not Bombs membagikan makanan kepada yang lapar dan orang-orang pada sebuah aksi protes. Food Not Bombs membantu dalam mempersiapkan sebuah gerakan aksi perlawanan nonkekerasan. Gerakan ini menentang rasisme, kelas, bias gender, homophobia, dan bentuk tindakan penindasan lainnya (Keith McHenry, 2012).

Prinsip-prinsip tersebut menjadi fondasi umum dari setiap cabang Food Not Bombs. Ada pula beberapa model kerja Food Not Bombs dalam mengorganisir aksinya. Model-model tersebut beragam di antara cabang-cabangnya. Relawan Food Not Bombs Boston akan berkeliling area Boston untuk mengumpulkan makanan yang tidak terjual dari penjual bahan makanan, toko roti, pasar. Setelah mengumpulkan bahan makanan maka mereka akan membagikan makanan ke proyek perumahan rakyat, dapur umum, tempat perlindungan, dan beberapa program yang menggunakan lainnya. Pengumpulan dan pengiriman makanan ini dilakukan secara rutin. Mereka mengirimkan bahan makanan sekali seminggu ke perumahan rakyat dan setiap hari ke tempat perlindungan yang besar atau dapur umum.

Sementara pengiriman tersebut, beberapa anggota Food Not Bombs yang lain akan menyiapkan makanan vegetarian untuk dibagi pada siang hari dan malam harinya. Dan mereka pula akan menyiapkan literature table di beberapa tempat di Boston. Food Not Bombs Boston juga menyediakan makanan dan tulisan di aksi protes di New England. Aksi tersebut berguna untuk memperkenalkan Food Not Bombs pada ratusan aktivis dan menarik anggota baru dan donasi makanan (Keith McHenry, 2012).

Besancon, Prancis juga memiliki cabang Food Not Bombs, yang berbeda dari cabang ini 
adalah mereka menggunakan musik dan pertunjukan seni bela diri untuk menarik perhatian orang di sekitarnya untuk datang ke literature table. Mereka membagikan makanan pada hari Sabtu di minggu pertama dan ketiga setiap bulannya. (Keith McHenry, 2012). Mereka mengadakan aksi mereka di depan toko infoshop di kota tersebut.

Di Yangon, Myanmar cabang FNB didirikan oleh sekelompok anggota band beraliran punk. Food Not Bombs Yangon berkeliling kota membagikan makanan dan baju kepada para tunawisma. Makanan yang dikumpulkan berdasarkan donasi yang diberikan masyarakat di daerah tersebut. Salah satu anggota Food Not Bombs tersebut mengatakan bahwa mereka bisa mendirikan Food Not Bombs dikarenakan pemerintahan baru yang terpilih pada tahun 2010 yang memberikan kebebasan untuk berkumpul (Daynews, 2015)

Para pencari suaka mendapatkan makanan yang dibagikan oleh anggota Food Not Bombs di Budapest, Hungaria. Pencari suaka ini berasal dari tempat berkonflik seperti Syria dan Afganistan. Makanan tersebut didapatkan dari donasi para pemilik toko makanan di pasar. Judit Maria, salah satu anggota Food Not Bombs daerah tersebut mengatakan bahwa orangorang ini telah melalui banyak hal jadi mereka terkejut ketika kami membantu tanpa meminta imbalan apa pun (UNHCR, 2015)

Food Not Bombs di Nairobi, Kenya membeli dan mengumpulkan makanan yang dapat dibuang karena memiliki dana tersendiri. Mereka menyewa kendaraan untuk membawa bahan makanan kemudian mengolahnya. Mereka memfokuskan pembagian makanan ke anak-anak yatim piatu dan pemuda kurang beruntung yang hidup di sana. Setelah kelas jurnalisme, menulis, dan fotografi dimulai dan diajarkan oleh para anggota Food Not Bombs (Keith McHenry, 2012).

Seperti yang digambarkan oleh beberapa model Food Not Bombs di atas, pengumpulan makanan dan pembagian makanan merupakan kegiatan utama Food Not Bombs. Selain itu Food Not Bombs pula menempati ruang publik selama beberapa jam dalam seminggu bahkan setiap hari dalam beberapa kota. Ruang publik ini menjadi ruang tempat Food Not Bombs menyiapkan literature table serta membagikan makanan yang telah mereka kumpulkan dan olah.

Food Not Bombs mengadakan pertemuan internasional pertamanya pada bulan Oktober 1992. Sekitar 75 orang dari sekitar tiga puluh cabang Food Not Bombs yang berada di Amerika Serikat dan Kanada datang untuk menghadiri pertemuan itu. Hal yang difokuskan oleh anggota pertemuan pada saat itu adalah prinsip-prinsip Food Not Bombs. Prinsip yang pertama adalah setiap cabang memiliki otonomi sendiri tanpa adanya pemimpin dan untuk menentukan keputusan dibutuhkan konsensus. Kedua, makanan yang dibagikan adalah makanan vegetarian dan gratis untuk semua orang tanpa batasan. Prinsip terakhir adalah dedikasi Food Not Bombs terhadap nonviolence direct action. Relawan yang datang pada acara tersebut setuju pula untuk membangun Food Not Bombs di kota-kota tetangganya (foodnotbombs.net, 2014).

PBB pada Juni 1995 mengadakan perayaan lahirnya di United Nation Plaza, San Fransisco. Food Not Bombs turut mengadakan pertemuan internasional yang kedua di San Fransisco. Hampir 600 orang yang berasal dari Amerika Serikat, Kanada, Australia, dan Eropa mendatangi pembukaan dari pertemuan tersebut. Pertemuan tersebut berlangsung selama 10 hari dari tanggal 15 sampai 26 Juni. Selama pertemuan tersebut Food Not Bombs menyatakan beberapa pandangan politiknya diantaranya menyuarakan deklarasi universal HAM (hak asasi manusia) (foodnotbombs.net, 2014).

Hari pembukaan pertemuan internasional FNB, banyak dari aktivis FNB ditangkap oleh polisi karena membangun beberapa instrumen yang terbuat dari kardus. Instrument tersebut dibuat untuk menyatakan bahwa bahkan di kota terkaya di dunia masih ada tunawisma dan pemerintah San Fransisco berusaha untuk menutupi hal tersebut selama perayaan lahirnya PBB di sana. Di hari berikutnya aktivis FNB menyebarkan tulisan mereka mengenai deklarasi universal HAM selama 10 hari. Di hari penutupannya, FNB mengadakan gerakan untuk melawan hukuman mati Mumia Abu-Jamal di Pennsylvania (foodnotbombs.net, 2014). Aktivis FNB dari beberapa negara di dunia makan, memasak, dan ditangkap bersama 
selama pertemuan internasional tersebut. Di hari terakhir setelah melakukan gerakan bersama, mereka berkumpul dan membahas untuk membangun sebuah kantor bersama. Hal ini diutarakan oleh beberapa volunteer yang sulit untuk menemukan FNB lokal mereka dan menghubungi FNB untuk informasi mengenai gerakan mereka. Maka FNB San Fransisco membuat website www.foodnotbombs.net sebagai tempat koordinasi global gerakan FNB (foodnotbombs.net, 2014). Aktifis Food Not Bombs juga ikut serta dalam Protes Anti Globalisasi di Seattle, Protes Perang terhadap Iraq dan Afganistan, dan menggagas The Drop Bush Not Bombs Tour, yaitu aksi prostes terhdap serangan AS ke Irak. Di Zagreb, pada tahun 2002 Food Not Bombs bersama dengan beberapa aktivis memulai kampanye "Stop NATO!" yang kemudian berubah menjadi kampanye No NATO. Setiap hari Sabtu selama satu setengah tahun kelompok ini mengorganisir aksi mereka di depan stasiun utama kota ini. Relawan dari beberapa kota turut datang dalam mendukung aksi dengan turut berpartisipasi. ${ }^{91}$ Sementara itu Food Not Bombs Sarajevo, Bosnia membagikan makanan dalam aksi kemah 600 hari. Aksi ini bertujuan untuk membantu penduduk informal yang telah menduduki aula kota pada Desember 2005 (Keith Mchenry, 2012).

\section{Mobilisasi Sumber Daya Manusia dan Materi Food Not Bombs}

Gerakan Sosial Baru seperti Food Not Bombs sangat mengutamakan identitas kolektif dalam mengidentifikasi sumber daya manusia yang mereka miliki serta sumber daya manusia di luar dari gerakan ini. Identitas kolektif Food Not Bombs terbangun atas sejarah gerakan anti perang pada tahun 1980an. Pendiri dari Food Not Bombs pula berasal dari aktivis yang menentang pembangunan stasiun nuklir. Di masa awal Food Not Bombs yaitu pada tahun 1980 sampai pada 1990 anggota Food Not Bombs saling mengidentifikasi diri mereka masing-masing dengan tujuan untuk menentang pembangunan nuklir dan mengakhiri perang.

Aksi solidaritas atas blokade warga Jerman terhadap misil Pershing 2, Music and March to End the Arms Race, dan konser Nuclear Disarmament menjadi tempat bagi Food Not Bombs untuk bertemu dengan aktivis-aktivis anti perang. Walaupun massa yang dimiliki oleh Food Not Bombs pada saat itu masih bersifat lokal. Barulah pada tahun 1992 dimana Food Not Bombs mengadakan pertemuan internasional pertama dimana anggota Food Not Bombs dari seluruh Amerika Serikat dan Kanada datang. Dengan mengadakan pertemuan tersebut hubungan antara anggota setiap cabang dapat saling menemukan keterhubungan. Hasilnya mereka menetapkan tiga prinsip yang dimiliki oleh Food Not Bombs.

Pada masa tersebut mobilisasi sumber daya manusia Food Not Bombs masih terbatas pada jaringan personal. Hal ini membuat aktivis yang ingin bergabung dengan Food Not Bombs lokal mereka menjadi sulit. Pada pertemuan internasional kedua Food Not Bombs, barulah Food Not Bombs membuat sebuah halaman internet bernama www.foodnotbombs.net. Situs halaman tersebut menjadi tempat koordinasi global gerakan Food Not Bombs. Dengan menggunakan situs tersebut anggota Food Not Bombs dapat menginformasikan kegiatan yang sedang berlangsung maupun yang akan direncanakan.

Pada tahun 1995, Food Not Bombs mengalami perluasan isu. Isu anti globalisasi atau keadilan sosial - social justice menjadi isu tambahan bagi Food Not Bombs. Perluasan isu tersebut menjadi faktor yang memungkinkan identitas kolektif yang lebih luas dari awal berdirinya. Aksi seperti Rent is Theft Tour, Unfree Trade Tour menjadi kegiatan menginformasikan kepada publik dan usaha untuk mengumpulkan massa pada aksi yang lebih besar yaitu aksi protes di Seattle.Food Not Bombs memiliki kemajemukan aktor yang memiliki latar belakang yang berbeda. Hal tersebut tercermin dari tidak adanya batasan yang jelas mengenai sistem keanggotaan Food Not Bombs. Gerakan sosial ini berusaha mengumpulkan massanya dari tingkatan rakyat. Sumber daya manusia Food Not Bombs dapat dinilai dengan keikutsertaan seseorang dalam proses aksi Food Not Bombs.

Food Not Bombs tidak memiliki sumber daya materi yang berasal dari sebuah institusi tertentu. Sumber utama materi Food Not Bombs berasal dari donasi masyarakat sekitarnya. Sumber daya materi yang berasal dari masyarakat sekitar menyebabkan adanya perbedaan 
dari sumber daya materi Food Not Bombs di setiap cabangnya. Bahan makanan menjadi salah satu materi utama bagi Food Not Bombs dalam melaksanakan aksinya.

Metode pengumpulan bahan yang sering dilakukan oleh Food Not Bombs biasanya berasal dari bahan makanan di pasar maupun toko yang akan dibuang dan masih dapat diolah. Dikarenakan bahan makanan yang dikumpulkan secara donasi, Food Not Bombs dalam melakukan aksinya tidak memerlukan biaya yang sangat besar secara operasional. Selain bahan makanan, materi logistik berupa alat memasak juga menjadi materi yang diperlukan. Pengumpulan sumber daya materi seperti ini sangat mudah untuk dilakukan sehingga menjadi salah satu faktor Food Not Bombs dapat dilakukan dengan mudah di kota manapun di dunia.

\section{Mobilisasi Sumber Daya Jaringan Komunikasi Food Not Bombs}

Salah satu dimensi transnasionalitas gerakan sosial adalah jaringan transnasional. Food Not Bombs juga memiliki jaringan transnasionalnya yang dikoordinasikan melalui situs halaman utama mereka. Dikarenakan sistem keanggotaan yang kurang jelas dan tidak mengikat maka jaringan yang dimiliki oleh Food Not Bombs bersifat informal. Ketika membutuhkan partisipasi lintas negara maka Food Not Bombs akan menuliskan ajakan mereka di situs tersebut. Situs tersebut menjadi ruang transnasional yang dimiliki oleh Food Not Bombs.

Komunikasi yang dilakukan setiap anggota maupun setiap cabangnya dilakukan pula melalui mailing list. Perencanaan Unfree Trade Tour dilakukan dengan adanya interaksi aktivis dari Spanyol dengan Food Not Bombs yang berada di San Fransisco. Mereka mengkomunikasikan perencanaan mereka melalui e-mail masing-masing. Media komunikasi lintas negara Food Not Bombs sangat bergantung pada komunikasi melalui e-mail. Hal ini disebabkan partisipasi anggota maupun cabang Food Not Bombs dalam sebuah kegiatan cabang lainnya bukanlah hal yang wajib.

\section{Strategi Aksi Food Not Bombs}

Food Not Bombs menganut prinsip nonkekerasan dalam menjalankan kegiatannya. Kegiatan protes nonkekerasan dan anti perang menjadi landasan utama strategi Food Not Bombs dalam mengkampanyekan protes mereka. Aksi umum yang mereka lakukan adalah membagikan makanan di ruang publik dan mengkampanyekan protesnya melalui literature table. Proses tersebut merupakan framing Food Not Bombs.

Di pertemuan internasional pertama Food Not Bombs mulai menekankan nilai dan landasan aksi mereka dengan menetapkan prinsip-prinsipnya. Prinsip-prinsip tersebut menjadi landasan strategi aksi Food Not Bombs. Makanan vegetarian dan gratis kepada semua orang tanpa melihat latar belakang, dedikasi kepada perubahan sosial nonkekerasan, dan otonomi setiap cabang.

Kesempatan politik seperti adanya agenda pertemuan WTO di Seattle, Invasi yang dipimpin oleh Amerika Serikat di Iraq dan Afghanistan, dan Pertemuan PBB menjadi kesempatan besar bagi Food Not Bombs. Kesempatan ini kemudian membutuhkan strategi-strategi untuk dimanfaatkan. Begitu pula kesempatan tersebut membuka jalan bagi Food Not Bombs untuk berinteraksi secara transnasional.

\section{Membagikan makanan kepada publik}

Membagikan makanan merupakan salah satu aksi penting dalam Food Not Bombs. Bagi gerakan ini mengumpulkan dan membagikan makanan merupakan cara khas dalam mengajak orang-orang masuk ke klaim mereka. Dalam artian hal tersebut merupakan framing Food Not Bombs. Cara tersebut menjadi sebuah strategi bagi Food Not Bombs untuk mengajak orang-orang ke dalam klaim mereka. Pembagian makanan ini secara umum dilakukan di ruang publik untuk menjangkau orang yang banyak. Food Not Bombs membagikan makanan di ruang publik secara rutin. Rutinitas pembagian makanan ini menjadi sangat penting bagi Food Not Bombs sebagai sebuah gerakan. Aksi yang berkelanjutan ini menandakan Food Not Bombs sebagai sebuah gerakan sosial. 
Meskipun setiap cabang bersifat independen, aksi pembagian makanan menjadi aksi yang membedakan gerakan ini dengan gerakan perdamaian lainnya. Pembagian makanan tersebut dapat dikategorikan sebagai usaha Food Not Bomb dalam mengkampanyekan anti kekerasan struktural. Hal tersebut membuat hubungan erat dengan kampanye-kampanye perdamaian positif yang diutarakan oleh Galtung.

Food Not Bombs pada dekade awal sangat menentang penggunaan uang negara untuk senjata militer daripada untuk kebutuhan pangan masyarakatnya. Penyampaian pesan tersebut dilakukan dengan membagikan makanan. Di dekade selanjutnya Food Not Bombs pula menghubungkan gerakan mereka dengan isu anti globalisasi atau keadilan sosial. Pembagian makanan tanpa mengenal latar belakang merupakan sebuah simbol yang digunakan untuk menyampaikan pesannya. Pembagian makanan secara rutin yang dilakukan oleh setiap cabang Food Not Bombs di penjuru dunia menjadi sebuah aksi yang terhubung secara global.

Food Not Bombs juga melakukan pembagian makanan di beberapa protes yang dilakukan oleh koalisi ataupun gerakan sosial lainnya. Dalam aksi yang dilakukan selama berhari-hari kebutuhkan logistik menjadi sangat penting. Aksi kemah, maupun pendudukan sebuah ruang maupun gedung tentu saja membutuhkan logistik. Pembagian makanan oleh Food Not Bombs menjadi sebuah elemen yang dapat membuat aksi teesebut bertahan.

Food Not Bombs menjadi salah satu kelompok yang membagikan makanan di protes anti globalisasi di Seattle. Begitu pula dengan aksi kemah yang diadakan oleh kelompok No Border dan Anarchist Against the Wall. Pembagian makanan bukan hanya sebagai strategi penyampaian pesan namun sebagai strategi untuk membuat aksi berlangsung lebih lama.

\section{Penggunaan metode nonkekerasan}

Nonkekerasan pada Food Not Bombs tidak dapat dipisahkan dikarenakan hal tersebut merupakan salah satu prinsip dari Food Not Bombs. Kampanye perdamaian yang dilakukan oleh Food Not Bombs semuanya memikirkan aspek nonkekerasan. Food Not Bombs menggunakan metode protes dan intervensi secara nonkekerasan dalam aksinya. Protes secara nonkekerasan merupakan aksi pertentangan secara damai tapi tidak sampai pada penolakan kerjasama atau secara langsung mengintervensi sebuah situasi. Intervensi secara nonkekerasan berbentuk keterlibatan langsung dari orang yang bukan bagian dari konflik (Johansen, 2007).

Pawai yang dilakukan oleh Food Not Bombs di depan laboratorium Draper dan aksi solidaritas protes warga Jerman terhadap misil Pershing 2 adalah bentuk protes secara nonkekerasan Food Not Bombs. Food Not Bombs kembali melakukan pada saat protes anti globalisasi di Seattle. Begitu pula dengan keikutsertaan Food Not Bombs dalam pawai European Social Forum. Pawai tersebut menjadi sebuah bentuk penyampaian pesan Food Not Bombs terhadap perlawanannya terhadap targetnya. Pawai berjalan menggunakan sebuah rute dapat menyampaikan pesan kepada publik dengan lebih besar dikarenakan posisi aksi yang luas.

Berkumpul untuk melakukan protes merupakan aksi yang paling sering digunakan oleh Food Not Bombs. Pada saat berkumpul di suatu tempat tersebut Food Not Bombs mengadakan beberapa aksi di tempat berkumpul tersebut. Aksi aksi tersebut antara lain berkemah, demonstrasi, presentasi, dan mengundang seniman. Aksi berkumpul ini mengumpulkan massa besar di suatu tempat.

Di awal Food Not Bombs aksi dengan berkumpul ini dilakukan pada saat pertemuan internasional pertama pada tahun 1992 dan kedua pada 1995. Pada pertemuan internasional kedua Food Not Bombs melihat hari lahir PBB sebagai kesempatan politik. Maka Food Not Bombs mengumpulkan aktivis Food Not Bombs dari seluruh dunia untuk berkumpul bersama di San Fransisco. Aksi di dekat monumen penghargaan kepada Deklarasi Universal HAM menjadi salah satu langkah untuk memperkuat pesan politik yang ingin disampaikan oleh Food Not Bombs.

Food Not Bombs Rusia dan Ukraina bekerja sama dengan aktivis No Border mengadakan 
kemah di perbatasannya. Mereka pula mengadakan pertemuan internasional di luar Amerika Serikat untuk pertama kali. Usaha tersebut merupakan bentuk strategi nonkekerasan yang memiliki tujuan yang sama dengan pawai. Begitu pula dengan Food Not Bombs cabang di Jerman dan Polandia mengadakan aksi yang sama. Strategi ini dilakukan dengan menggunakan fenomena permasalahan migrasi di Eropa.

Perang terhadap Iraq dan Afghanistan yang dipimpin oleh Amerika Serikat menjadi salah satu kesempatan politik yang besar bagi Food Not Bombs dalam upayanya mengkampanyekan perdamaian. Sebagai hasilnya Food Not Bombs di kota-kota besar di beberapa negara mengadakan protes dan intervensi. Aksi yang dilakukan oleh Food Not Bombs bervariasi dalam kampanye ini.

Food Not Bombs di Irlandia ikut serta dalam aksi blokade di pangkalan udara Shannon. Food Not Bombs di kota Zagreb pula mengikuti protes di depan kedutaan Amerika Serikat di Kroasia. Bentuk aksi seperti ini merupakan sebuah aksi yang masuk dalam kategori intervensi nonkekerasan. Dimana Food Not Bombs Irlandia dan Zagreb bukan pihak yang berkonflik.

Dengan adanya prinsip otonomi di setiap cabangnya, Food Not Bombs memiliki strategi yang berbeda. Berbeda dengan Zagreb dan Irlandia, Food Not Bombs Drusseldorf mengadakan pawai untuk menyampaikan kampanyenya. Tanpa adanya keterikatan maupun persamaan tersebut strategi Food Not Bombs secara menyeluruh beragam dalam kampanye anti perangnya terhadap Perang yang dipimpin Amerika Serikat di Iraq dan Afghanistan. Walaupun beragam aksi-aksi tersebut masih memegang prinsip nonkekerasan.

Dalam sebuah aksi nonkekerasan Food Not Bombs tidak hanya menggunakan satu aksi saja. Kelompok ini juga membuat metode-metode nonkekerasan sebagai sebuah rangkaian. Pada Aksi protes di Seattle yang berlangsung selama beberapa hari Food Not Bombs tidak hanya berkumpul dan membagikan makanan akan tetapi juga melakukan pawai. Merangkaikan metode nonkekerasan ini memberi dinamika dalam aksi yang dilakukan selama aksi protes tersebut.

\section{Membangun Koalisi Transnasional}

Agenda Pertemuan WTO di Seattle menciptakan sebuah kesempatan bagi Food Not Bombs untuk berkoalisi dengan kelompok yang menentang WTO.Protes anti globalisasi di tahun 1999 di Seattle menjadi salah satu aksi koalisi aksi dimana seluruh aktivis dunia berkumpul. Food Not Bombs menjadi salah satu kelompok gerakan sosial yang berkoalisi dalam aksi tersebut. Food Not Bombs bersama dengan organisasi Seeds of Peace, aktivis buruh, aktivis lingkungan, kelompok social justice, dan kaum anarkis berkumpul dari 29 November sampai 3 Desember 1999. Food Not Bombs menjadikan WTO sebagai targetnya dapat membuka kesempatan berkoalisi dengan kelompok-kelompok tersebut.

Koalisi tersebut mampu mengumpulkan lebih dari 50.000 sampai 100.000 orang di Seattle. Dengan menggunakan koalisi kemampuan mobilisasi massa Food Not Bombs bertambah. Sebelum hari protes tersebut Food Not Bombs pula membangun kerjasama dengan Earth First! untuk mengadakan tur bersama di Amerika Utara. Sumber daya manusia yang masih terkonsentrasi di negara Amerika Serikat, Food Not Bombs menggunakan koalisi bersama dengan kelompok tersebut untuk mencapai wilayah aksi yang lebih luas lagi yaitu Amerika Utara.

Koalisi transnasional lainnya terjadi pada aksi protes perang di Iraq dan Afganistan. Kali ini Food Not Bombs bekerja sama dengan berbagai organisasi anti perang seperti United for Peace and Justice, Veterans for Peace, dan September Families for Peaceful Tomorrow. Kesempatan politik seperti ini membawa Food Not Bombs membangun kerjasama dengan organisasi anti perang lainnya.

Di Eropa, koalisi Food Not Bombs dengan No Border terebar di benua ini. Permasalahan imigrasi menjadi focus utama koalisi ini terjadi. Di perbatasan Ukraina-Rusia dan perbatasan Polandia-Jerman menjadi dua tempat kegiatan koalisi ini. Food Not Bombs juga bekerja sama dengan Anarchist Against the Wall dalam aksi di perbatasan Palestina dan Israel. 
Koalisi yang dibangun oleh Food Not Bombs di Seattle dan selama Perang Iraq dan Afghanistan merupakan koalisi jangka pendek. Koalisi tersebut berakhir ketika sebuah aksi besar telah dilakukan seperti pada saat aksi anti globalisasi di Seattle. Koalisi tersebut berakhir dengan berakhirnya aksi protes di Seattle pada tanggal 3 Desember. Begitu pula dengan koalisi Food Not Bombs dengan Earth First! Dalam "Unfree Trade Tour" koalisi tersebut berakhir setelah tur selesai. Koalisi yang dibangun ini hanya terjadi pada skala kegiatan atau aksi tersebut berlangsung.

Membangun koalisi dengan aktivis dan organisasi dengan target yang sama menjadi sangat menguntungkan. Apalagi dengan target aktor supranasional seperti WTO dan PBB. Kekuatan sebuah gerakan sosial yang bergerak di tingkatan rakyat (grassroots) sendiri sangat dipengaruhi oleh kemampuan mobilisasi massanya.

\section{Food Not Bombs dalam Upaya Pencapaian Perdamaian}

Gerakan sosial Food Not Bombs sangat dipengaruhi oleh nilai dan norma yang mereka miliki. Selama beberapa dekade semenjak berdirinya Food Not Bombs, terdapat berbagai dinamika dan fenomena internasional yang terjadi. Fenomena internasional seperti Pertemuan PBB, WTO, dan invasi yang dipimpin oleh Amerika Serikat di Iraq dan Afghanistan membawa beberapa peluang bagi Food Not Bombs.

Pada tahun 1980an, gerakan perdamaian didominasi oleh gerakan anti nuklir. Food Not Bombs tidak terkecuali dan bahkan pada awalnya anggota gerakan ini didominasi oleh aktivis anti nuklir. Seperti pada protes gerakan ini pada saat PBB mengadakan pertemuan dan protes di depan laboratorium Draper. Pada saat isu anti globalisasi atau keadilan sosial memuncak dengan banyaknya aktivis-aktivis anti globalisasi bermunculan di dunia. Food Not Bombs kemudian memperluas isu dengan mengikuti beberapa aksi protes terhadap globalisasi. Salah satunya adalah dengan mengikuti aksi protes besar di Seattle. Hal ini membuktikan isu Food Not Bombs kemudian tidak hanya berada pada isu anti perang dan militer melainkan juga ke isu anti globalisasi. Perluasan ini menunjukkan fleksibilitas Food Not Bombs dalam isu-isu perdamaian.

Keberagaman isu tersebut kemudian dapat pula dihubungkan terhadap isu lokal setiap cabang Food Not Bombs. Hal ini memudahkan bagi Food Not Bombs dalam beradaptasi. Adaptasi yang dimaksudkan adalah isu Food Not Bombs sesuai dengan isu atau fenomena lokal yang terjadi. Seperti isu imigrasi yang diangkat oleh Food Not Bombs Ukraina dan Rusia sementara di Amerika Serikat mengangkat isu pembiayaan militer Amerika Serikat. Aktivis dapat dengan mudah mendirikan cabang Food Not Bombs sendiri di kota mereka karena tidak perlu menyesuaikan isu yang berada di cabang lain.

Sistem otonomi dan independensi cabang-cabang Food Not Bombs memberi peluang keberagaman isu-isu yang ada dalam Food Not Bombs.dengan beragamnya isu tersebut peluang terlibatnya aktivis-aktivis maupun aktor-aktor dari latar belakang isu yang berbeda menjadi besar. Isu yang luas dan beragam tersebut juga memberi peluang yang besar untuk membangun kerjasama maupun koalisi dengan gerakan sosial lainnya. Kerjasama Food Not Bombs dengan Earth First! yang merupakan organisasi advokasi lingkungan menjadi salah satu contoh fleksbilitas Food Not Bombs.

Bagi gerakan sosial yang berada pada tingkatan grassroots seperti Food Not Bombs anggota yang tidak terikat menjadi salah satu karakteristiknya. Dimensi transnational network menjelaskan jaringan informal merupakan salah satu keuntungan yang dimiliki oleh gerakan sosial seperti Food Not Bombs. Jaringan informal ini juga membuka kesempatan bagi mobilisasi lintas negara seperti yang terjadi pada Unfree Trade Tour. Dalam tur tersebut Food Not Bombs dari Amerika Serikat berkomunikasi dan bertukar ide dan strategi dengan Food Not Bombs yang berada di Italia. Jaringan informal yang digunakan adalah melalui komunikasi media internet seperti e-mail.

Salah satu pula media yang digunakan adalah situs halaman utama sebagai tempat memberitakan kegiatan-kegiatan Food Not Bombs. Hal ini dapat pula memicu terjadinya diffusion. Peniruan di kota-kota lain dapat pula berasal dari media virtual seperti situs tersebut. 
Food Not Bombs dalam melakukan kampanye perdamaiannya selama 30 tahun lebih mengalami beberapa hambatan. Hambatan yang dialami oleh Food Not Bombs berbeda di setiap cabangnya. Terdapat beberapa hambatan yang umum di antara cabang-cabang ini. Kurangnya dukungan otoritas setempat menjadi hambatan yang dihadapi oleh Food Not Bombs. Pada tanggal 15 Agustus 1988 di San Fransisco, Amerika Serikat sembilan orang aktivis Food Not Bombs ditangkap pada saat membagikan makanan (Keith McHenry, 2012) Di San Fransisco sendiri lebih dari 1000 penangkapan telah dilakukan oleh polisi setempat. Hal yang sama juga dialami oleh aktivis Food Not Bombs di Guadalaraja, Meksiko dimana sebelas orang dari mereka ditangkap oleh polisi.

Koordinasi yang melibatkan Food Not Bombs secara global menjadi hal yang sangat jarang terjadi. Tidak seperti gerakan Earth Hour yang memiliki gerakan yang terkoordinasi dengan waktu yang sama. Food Not Bombs tidak memiliki koordinasi global seperti itu. Salah satu penyebabnya adalah sulitnya berkomunikasi secara global kepada anggota Food Not Bombs di setiap cabang. Food Not Bombs juga tidak memiliki komunikasi yang dilakukan secara rutin. Adapun pertemuan yang diadakan oleh Food Not Bombs tidak dilakukan secara berkala. Pertemuan internasional yang diadakan oleh Food Not Bombs terjadi pada tahun 1992, 1995, dan 2007 selama 30 puluh tahun semenjak gerakan ini bermula. Jarangnya pertemuan internasional ini pula mengurangi interaksi Food Not Bombs dalam skala besar.

Ketergantungan kepada email menjadi salah satu kelemahan Food Not Bombs. Keterlibatan semua cabang Food Not Bombs dalam sebuah isu bersama menjadi hal yang sangat jarang terjadi. Aksi bersama yang melibatkan banyak cabang Food Not Bombs dalam satu isu hanya pada Perang Iraq dan Afghanistan. Koalisi-koalisi yang terbangun dalam protes anti globalisasi yang diikuti oleh Food Not Bombs juga merupakan koalisi jangka pendek. Tidak seperti koalisi yang terjadi di European Social Forum dan World Social Forum. Sehingga koalisi yang terbangun hanya sebatas koalisi pada suatu event saja seperti yang terjadi pada koalisi di Seattle.

\section{KESIMPULAN}

Food Not merupakan gerakan sosial yang bergerak di isu perdamaian. Gerakan sosial ini telah melakukan beberapa aksi dalam mengkampanyekan perdamaiannya. Perkembangan gerakan ini sangat cepat di tingkatan transnasional. Seperti semua gerakan sosial, Food Not Bombs juga memiliki target ataupun simbol yang mereka lawan. Dalam menyampaikan pesan maupun pernyataan politiknya Food Not Bombs memiliki strategi-strategi dan beberapa peluang serta hambatan.

Sistem keanggotaan yang longgar dan fleksibel menjadikan Food Not Bombs dapat dengan mudah menarik dan mengajak orang-orang untuk ikut dalam aksinya. fleksibilitas tersebut berasal dari tidak adanya batasan latar belakang untuk menjadi anggota Food Not Bombs. Sehingga gerakan ini dapat dengan mudah mengajak orang di tingkatan grassroots. Perluasan isu dari hanya pada anti perang ke anti globalisasi menjadi salah satu faktor pertambahan sumber daya manusia Food Not Bombs. Hal tersebut memungkinkan memperluas identitas kolektif yang dimilikinya. Sehingga aktor-aktor dapat menghubungkan dirinya kepada Food Not Bombs. Contohnya proyek Unfree Trade Tour yang menjadi kegiatan menginformasikan dan mengajak massa ke aksi protes WTO di Seattle.

Pesan anti perang dan kelaparan yang dimiliki oleh Food Not Bombs disimbolkan dengan membagikan makanan tanpa mengenal latar belakang. Pembagian makanan ini merupakan bentuk framing Food Not Bombs. Membagikan makanan ini menjadi kegiatan rutin yang dilaksanakan oleh Food Not Bombs di masing-masing cabangnya. Nonkekerasan merupakan prinsip yang dimiliki oleh Food Not Bombs.dalam melaksanakan aksinya. Metode kampanye nonkekerasan yang dilakukan oleh Food Not Bombs diantaranya protes dan intervensi nonkekerasan. Metode ini kemudian dibagi menjadi beberapa aksi kecil yang seringkali dirangkaikan ketika aksi yang dilakukan berlangsung lama. 
Volume 1, No 1 - February 2021

\section{DAFTAR PUSTAKA}

BUKU:

Cohen dan Rai, Global Social Movement, The Athlone Press, 2000.

Della Porta dan Tarrow, Transnational Protest \& Global Activism, Maryland: Rowman \& Littlefield Publisher, 2005.

Della Porta dan Diani, Social Movement An Introduction, Oxford: Blackwell Publishing, 2006.

Galtung, Johan, "Violence, Peace, and Peace Research," dalam Journal of Peace Research, New York: Sage Publication, 1969.

Galtung, Johan, Peace by Peaceful Means: Peace and Conflict, Development and Civilization, terj. Asnawi dan Safruddin, Surabaya: Pustaka Eureka, 2003.

Johansen, Jorgen, Nonviolence More than the Absence of Violence, dan Galtung (ed), Handbook Of Peace and Conflict Studies, London: Routledge, 2007.

Khagram, dkk, Restructuring World Politics: Transnational Social Movements, Networks, And Norms, Minneapolis: University of Minnesota Press, 2002.

McHenry, Keith, Hungry for Peace, Tucson: See Sharp Press, 2012 McHenry, Keith, Cooking For Peace With Food Not Bombs Cultivating Community, Reaping Revolution, Tucson: See Sharp Press, 2010.

Navarro dan Nario, Peace Education: A Pathway to a Culture of Peace, Quezon: Center for Peace Education, 2008.

Singh, Rajendra, Gerakan Sosial Baru, Yogyakarta: Resist Book, 2010 Tarrow, Sidney, The New Transnational Activism, New York: Cambridge University Press, 2005

Webel, Charles, Introduction Toward a Philosophy and Metapsychology of Peace, dalam Webel dan Galtung (ed), Handbook Of Peace and Conflict Studies, London: Routledge, 2007.

Wienclaw dan Howson, Major Social Movement, dalam The Editors of Salem Press (ed), Theories of Social Movements, California: Salem Press, 2011

JURNAL DAN ARTIKEL:

Baharuddin, Aswin, Rial Ashari Bahtiar, and Seniwati Ismail. "The Idea And The Strategy Of Transnational Social Movement About Right To The City In Indonesia." Journal of Humanity and Social Justice 1.1 (2019): 72-94.

Carty dan Onyett, Protest, Cyberactivism and New Social Movements: The Reemergence of the Peace Movement Post 9/11, dalam Social Movement Studies: Journal of Social, Cultural and Political Protest, vol. 5, London: Routledge, 2006.

Emily Rojer, "Food Not Bombs: A Radical Organization?," dalam Lehig Review Vol. 9, Bethlehem: Lehigh Preserve, 2011.

Hermann Maiba, Grassroots Transnational Social Movement Activism: The Case Of People's Global Action, dalam Sociological Focus, Vol. 38, No.1, London: Taylor \& Francis, 2005

WEBSITE:

Afghanistan War: 2001 - 2002, http://warchronicle.com/afghanistan/news/timeline.htm, diakses pada tanggal 6 Desember 2014 pkl. 23. 48 WITA

Burmese Punk Band Members Regularly Feed Their Homeless in Yangon, http://www.daynews.com/world/local-news/2015/07/burmese-punk-band-membersregularly-feed-the-homeless-in-yangon-25197, diakses pada tanggal 1 Agustus 2015, pkl. 22.08 WITA

CASTOR, http://www.nuclear-heritage.net/index.php/Castor. Diakses pada tanggal 6 Januari 2015 pkl. 02.27 WITA

Cities Jammed in Worldwide Protest of War in Iraq, http://edition.cnn.com/2003/US/02/15/sprj.irq.protests.main, diakses pada tanggal 29 September 2014 pkl. 21.22 WITA 
Definisi kata strategi, http://kbbi.web.id/strategi, diakses pada tanggal pada tanggal 23 April 2014 pkl. 21.37 WITA

EU Allies Unite Against Iraq War, http://news.bbc.co.uk/2/hi/europe/2683409.stm, diakses pada tanggal 6 Desember 2014 pkl. 19.03 WITA

Food Not Bombs Literature Table Solidarity Not Charity, http://www.foodnotbombs.net/literature_table.html, diakses pada tanggal 26 September 2014, pkl. 21.43 WITA

Food Not Bombs Literature Table Solidarity Not Charity, http://www.foodnotbombs.net/literature_table.html diakses pada tanggal 26 September 2014, pkl. 21.43 WITA

Hamilton, William, Bush Began to Plan War Three Months After 9/11, http://www.washingtonpost.com/wp-dyn/articles/A17347- 2004Apr16.html/, diakses pada tanggal 8 Desember 2014 pkl. 19.35 WITA

Iraq War Timeline, http://warchronicle.com/iraq/news/timeline_iraq_war.htm, diakses pada tanggal 9 Desember 2014 pkl. 02. 11 WITA

Linder, Balint, Lending A Hand In Hungary, http://tracks.unhcr.org/2015/07/lending-a-hand-inhungary/,diakses pada tanggal 1 Agustus 2015, pkl. 22.37 WITA

Ljubic, Darko, Food Not Bombs! Collectives, http://www.rhythmchanges.info/index.php?option=com_content\&task=view\&id=27\&lte mid=44.Diakses pada tanggal 8 Januari 2015 pkl.03.54 WITA message from participants at the Ukraine No Border Camp, http://www.indymedia.org.uk/en/2007/08/378243.html, diakses pada tanggal 15 Januari 2015 pkl. 23.16 WITA

Shah, Anup, WTO Protest in Seattle, 1999, http://www.globalissues.org/article/46/wtoprotests-in-seattle-1999, diakses pada tanggal 4 Desember 2014 pkl. 23.09 WITA

The 25th Anniversary of Food Not Bombs Part 3 Food Not Bombs Becomes A Worldwide Movement, http://www.foodnotbombs.net/z_25th_anniversary_3.html, diakses pada tangggal 1 Oktober 2014 pkl. 02. 33 WITA

The Three Principles of Food Not Bombs, http://www.foodnotbombs.net/principles.html, diakses pada tanggal 6 November 2014 pkl. 20.17 WITA

Timeline of the Major Events in the History of Food Not Bombs, http://www.foodnotbombs.net/fnb_time_line.html,diakses pada tanggal 29 September 2014 pkl. 22.04 WITA

World Bank Group Infoshop Bookstore ,http://www.worldbank.org/en/publication/infoshop, diaksespada tanggal 29 September 2015, pkl. 19.44 WITA 